\title{
NADCHODZI REWOLUCJA! KRYTYKA POPNAUKOWYCH PRÓB PRZEWIDYWANIA PRZYSZLOŚCI
}

Adrian D. Wesołowski

Instytut Antropologii Społecznej Towarzystwa Maxa Plancka, Halle, Niemcy

Uniwersytet Warszawski

Prz̨ekonań nie zdobywa sie tatwo, a jeśli dochodzi sie do nich bez. trudu, okazuje sie wkerótce, że sa berwartościowe i niezdolne stawić opór w walce.

Zygmunt Freud, Vorlesungen zur Einführung in die Psychoanalyse, 1916-1917

Jeżeli jest sie uczcinym i unika sie interpretacji, patroszenie drobiu w celu przenwidzenia praysz̨ości jest, do pewnego stopnia, randomizacja. Ale z kogucich wnetrzności niełatwo crytać bez fatszerstwa lub dawania ponieśś sie fantazji.

Ian Hacking, The Emergence of Probability, 1975

Rewolucje sa problemem badawczym, z którym socjologowie historyczni i teoretycy społeczni mierzą się co najmniej od czasów Karola Marksa. Przez pokolenia fluktuacji między entuzjazmem a sceptycyzmem wobec możliwości naukowego opisania problemu badacze zbudowali szereg teorii stosujących się do rewolucji zachodzących na polu społeczeństwa, życia intelektualnego, ekonomii czy technologii. W świecie akademickim panuje jednak głęboka nieufność wobec prób ogłaszania nowych rewolucji.

W tym świetle zaskakuje przegląd listy bestsellerów Notable Books „New York Timesa”, gdzie spośród prac akademickich wyróżnia się liczba tych, które zapowiadaja nadejście ogromnych, drastycznych zmian. Autorzy w rodzaju Stevena Pinkera czy Yuvala Noaha Harariego osiagaja zawrotny sukces: ich książki sprzedawane są w milionach egzemplarzy, tłumaczone 
na dziesiątki języków, a liczba ich cytowań liczona jest w tysiącach. Tymczasem wśród krytyków mówi się o zestawie cech - literackości i retoryce, opieraniu wniosków na wrażeniach, pogardzie wobec szczegółu, dystansie wobec metod nauk społecznych, braku jakiegokolwiek namysłu metodologicznego , promowaniu raczej niż proponowaniu przedstawianej idei oraz niewzruszonej wierze we własne wnioski - które znamionować mają trend obecny wśród naukowców, pisarzy i publicystów próbujących prognozować przyszłość w podobny sposób. Podobne tendencje wskazywały prace Roberta Wrighta (2001), Raya Kurzweila (2000, 2005) czy Michaela Shermera (2015). W dyskusji wokół tych prac często cytowane są również pozycje dotyczące sztucznej inteligencji, jak ważne dzieła Nicka Bostroma (2014) czy Maxa Tegmarka (2017), mimo że ich samych nie sposób zakwalifikować do grona pisarzy idących za wspomnianym trendem. Choć jest to zróżnicowana grupa, jej członków łączy m.in. identyfikacja z nurtem tzw. nowego ateizmu i przekonanie o możliwości mechanistycznego opisu zagadnień społecznych. Często stają oni po jednej stronie w publicznych debatach i wzajemnie polecaja swoje prace, tworzac rodzaj publicystycznego frontu skupionego wokół jednego prądu myślowego. Dla uproszczenia w dalszej części tekstu będę nazywał trend, o którym mowa, popnauką, w odróżnieniu od popularyzacji nauki dopuszczająca się uproszczeń i homogenizacji dyskursu akademickiego, i zachowująca przy tym przekonanie o naukowej metodzie dochodzenia do swoich śmiałych wniosków. Chociaż moga ich dzielić styl i metody pisania, popnaukowcy roszczą sobie prawo do naukowości, podczas gdy popularyzatorzy zachowują inne cele i tożsamość.

Nie sposób zupełnie wzgardzić odkryciami popnaukowców, którzy potrafią wnieść do debaty publicznej wiele nowych, wartościowych argumentów. Warto zadać jednak pytanie: czy w obliczu kolejnych rewolt, jakie sa przez nich zapowiadane, należy uznać, że odnaleźli oni lepszy sposób przewidywania przyszłych rewolucji niż tradycja socjologiczna? Poniższy tekst poświęcony jest rekonstrukcji modelu argumentacji, ciężaru dowodów, zakorzenienia metodologicznego oraz budowy aparatu naukowego w pracach Pinkera oraz Harariego jako przedstawicieli popnauki. Wybór tych autorów podyktowany został ich niezwykłym sukcesem i wpływem, jaki wywierają nie tylko na sferę publiczną, ale również na środowisko naukowe. Zasadność pisania o Pinkerze i Hararim jako popnaukowcach, pomimo że ich książki mają wiele mocnych stron, opiera się na ich niezwykłej popularności wśród akademików niezajmujących się profesjonalnie historią czy naukami społecznymi. W momencie, w którym to piszę, książka Pinkera ma w bazie Google Scholar ponad trzy tysiące zarejestrowanych 
cytowań, a z prac Harariego każda ma daleko ponad trzysta. Autorzy ci, wiedzeni chęcią przekazania ciekawego argumentu, utrwalają błędne rozumowania, z którymi muszą później walczyć faktyczni specjaliści, nieosiagający jednak podobnego rozgłosu. Powracającym wątkiem jest pojęcie rewolucji. Sposób, w jaki Pinker i Harari podeszli do tego zagadnienia, jest reprezentatywny dla szerszych tendencji metodologicznych charakteryzujących prace $z$ tego nurtu.

Skromne metody, które wykorzystano w poniższym tekście, opierają się na krytycznej analizie omawianych prac i porównaniu ich ze stanowiskiem środowiska naukowego. Ze względu na specyfikę zagadnienia ważnym źródłem uzupełniającym są też wywiady z autorami oraz liczne recenzje o mniej lub bardziej akademickim charakterze zamieszczone w prasie. Ostatnia, częściowo spekulatywna część artykułu sprowadza się do poszukiwania powiązań między zaobserwowanymi trendami i próby połączenia ich w sensowną całość. Próbuje ona odpowiedzieć na pytanie, czy nowy sposób pisania o rewolucjach wpisuje się w ramy szerszej tendencji oraz, jeśli tak, to skąd się ona bierze? Próba odnalezienia przyczyn prowadzi do pogłębionej kontekstualizacji okoliczności pojawienia się popnauki, ze zwróceniem szczególnej uwagi na tradycje intelektualne i wydawnicze świata anglojęzycznego.

\section{/// Rewolucyjny pokój Pinkera}

Książka Zmieræzch prz̨emocy. Lepsza strona naszej natury (2011a; polskie tłum. 2015) Stevena Pinkera podniosła argument o monumentalnym znaczeniu dla wszelkich nauk społecznych i wielu innych dziedzin. Jej oryginalność okazuje się jeszcze większa, kiedy dostrzeżemy, jak rzadko badacze nauk przyrodniczych zajmuja się opisem kulturowych, a nie biologicznych czynników determinujących ludzkie zachowanie (Pinker to amerykański psycholog eksperymentalny i kognitywista). Badacz twierdził, że na przestrzeni ludzkiej historii we wszystkich społeczeństwach zaobserwować można spadek poziomu przemocy, oraz uzależniał to zjawisko od postępu cywilizacyjnego. Przemoc rozumiał jako przemoc fizyczną (Pinker 2011b), która mierzy za pomocą współczynnika stosunku liczby gwałtownych śmierci do liczby ogólnej populacji danego społeczeństwa (Pinker 2011a: 31-35). Autor wytyczył swojej pracy trzy cele, które określiły zastosowane metody:

1. Udowodnienie, że spadek poziomu przemocy - od 8000 r. p.n.e. do XXI wieku - jest faktem. Narracja historyczna Pinkera nie kierowała się z góry ustalonym kwestionariuszem i pozbawio- 
na jest dogłębnej refleksji metodologicznej. Opisaniu metod poświęcono dwa akapity, w których autor zaznaczył dystans wobec prostych dualizmów i tworzenia iluzji linearnego, niepowstrzymanego postępu (Pinker 2011a: xxii-xxiii). Faktycznie, struktura części historycznej (s. 1-481) opiera się na opisie i próbie interpretacji imponującej liczby danych statystycznych na podstawie fragmentów źródeł oraz fragmentów teorii innych badaczy (w przeważającej mierze Norberta Eliasa). Pinker wyróżnił sześć prądów społeczno-historycznych obniżających poziom przemocy (proces pacyfikacyjny, proces cywilizacyjny, rewolucja humanitarna, Długi Pokój, Nowy Pokój, rewolucje praw mniejszości).

2. Sformułowanie wniosków z zakresu psychologii przemocy, oparte na neurobiologii i kognitywistyce oraz społecznej i ewolucyjnej psychologii (Pinker 2011a: xxiii). Pinker powiązał obserwacje wynikające z badań psychologicznych ze skorelowanymi rezultatami badań neurobiologicznych oraz mapowaniami mózgu i podbudował zauważone korelacje rozbudowana teoria kognitywną, w której ważną rolę odegrała jego własna erudycja (s. 482-670). Efektem było wyróżnienie wrodzonych tendencji skłaniających do przemocy lub jej braku, ,aniołów” (empatia, samokontrola, poczucie moralności, rozsądek) i „demonów” ludzkiej natury (pragmatyczna bądź drapieżnicza przemoc, chęć dominacji, chęć zemsty, sadyzm, ideologia); napięcie pomiędzy nimi miało określać skłonności do przemocy lub ich brak.

3. Wyjaśnienie, jaką rolę odgrywają czynniki psychologiczne w rozwoju naszego stosunku do przemocy na gruncie przekształceń historycznych. Pinker skierował się w stronę poszukiwań egzogennych czynników determinujących zmianę społeczną (Pinker 2011a: xxiii). W tym celu użył stworzonych wcześniej kategorii, stawiając pytanie o to, jakie powtarzające się w różnych prądach społeczno-historycznych (proces pacyfikacyjny itd.) elementy przyczyniały się do stłamszenia „demonów” ludzkiej natury przez jej ,,anioły”. Skutkiem prowadzonej w ten sposób analizy było odnalezienie pięciu „sił historycznych” kierujących społeczeństwa ludzkie w stronę pokoju (upaństwowienie, handel, feminizacja, kosmopolityzm, racjonalizm).

Mimo niewatpliwej popularności praca Pinkera wzbudziła również wiele krytycznych reakcji. Nieznacznym echem odbiły się relatywizujące pojęcie przemocy ataki ze strony perspektywistów (Laws 2011, True 2015); 
autor Zmierz̨chu przemocy z łatwością obronił się też przed oskarżeniem o zachodni ekskluzywizm, wysuniętym przez postmodernistów (Kolbert 2011, Pinker 2011b). Wśród poważniejszych zarzutów znalazło się uleganie prostym mitom historycznym (Douthat 2011, Jervis 2011). Podważano zasadność stosowania danych historycznych do skutecznego opisu dzisiejszych trendów społecznych, często pozostających w sprzeczności z ustaleniami Pinkera (Epstein 2011), szczególnie w kwestii ilościowej oceny zjawiska przemocy (Lerner 2012, Arquilla 2012), oraz jego wyjaśnienie przyczyn długiego pokoju przy zignorowaniu eksportu wojen do państw zależnych od zachodnich potęg (Gray 2011). Na bardziej podstawowym poziomie często powracały krytyki arbitralnego doboru źródeł pod z góry ustalona tezę (Epstein 2011, Aronson 2013, Ferguson 2013, Mitzen 2013) oraz zarzut promowania światopoglądu - oświeconego humanizmu - jako głównej motywacji do napisania pracy (Gray 2011, Lerner 2012, Bhatt 2013).

Z perspektywy historyka dostrzec można kolejne braki w zastosowanej przez Pinkera metodzie. Jego analiza historyczna jest niemal pozbawiona namysłu metodologicznego. W pracy brak charakterystyki czy delimitacji zakresu materiałów, na których opiera się autor. W rezultacie pierwsze rozdziały Zmierz̨chu przemocy składają się z omówienia arbitralnie dobranych kontrastów pomiędzy dawnymi przykładami przemocy (czerpanymi z literatury oraz zbioru popularnych znalezisk archeologicznych) a tym, jak dziś często się ją wyobraża, oraz pozbawionego kontekstu omówienia konceptów filozoficznych, które według Pinkera charakteryzować mają epoki, w których powstały. Takie podejście pogłębia podejrzenie o impresyjny dobór źródeł. Ilość miejsca przeznaczonego na przedstawienie danych historycznych (481 stron) i analizę psychologiczną (182 strony) góruje nad, zdawałoby się, kluczowym fragmentem poświęconym interpretacji tych zależności i konceptualizacji wniosków (zaledwie 25 stron). Zestawiając te obserwacje z popularnością Zmierzchu przemocy, Edward Herman stwierdził, że ,jest to okropna książka, zarówno pod względem warsztatu badawczego, jak i jako przewodnik po realiach", choć jest świetnie dostrojona do popytu, jaki panuje wśród amerykańskich i zachodnich elit początków XXI wieku (Herman i Peterson 2012).

Krytyka Pinkera jest kontekstem koniecznym do zrozumienia jego podejścia do tematu rewolucji. Jednocześnie jego myślenie o rewolucjach reprezentuje typowe dla niego pominięcia, skróty myślowe oraz postawę badawczą. Pinker posługuje się pojęciem rewolucji wielokrotnie, przede wszystkim odnosząc się do rewolucji neolitycznej, rewolucji przemysłowej oraz rewolucji politycznych (amerykańskiej i francuskiej), za pewnik przyj- 
muje również koncept rewolucji militarnej, do którego wielu historyków odnosi się sceptycznie (Duffy 1980, Black 1995, Pinker 2011a: 72-80). Bezkrytycznie przyjmuje również określenia odnoszące się do kultury, jak rewolucja humanitarna czy seksualna. Stosowany przez Pinkera termin „rewolucje praw” jest po prostu nazwą na ruchy społeczne domagające się egzekucji istniejących bądź nadania specjalnych praw grupom mniejszościowym lub dyskryminowanym; chodzi o prawa kobiet, dzieci, mniejszości seksualnych i zwierząt (Pinker 2011a: 378-380). Centralny argument książki w żadnym stopniu nie opiera się na dotychczasowych ustaleniach myśli społecznej; nawet Eliasa Pinker cytuje jedynie anegdotycznie. Autor nie wydaje się przejmować konsekwencjami teoretycznymi przyjmowanych pojęć. Rewolucja to tylko inna nazwa na zmianę.

Takie podejście powinno głęboko dziwić nie tylko ze względu na to, że ignorancja wobec wcześniejszych ustaleń badaczy podważa centralny argument książki, ale również dlatego, że sam Zmierz̨ch præ̨emocy krąży wokół dwóch silnie rewolucyjnych wątków. Pierwszy dotyczy wysiłków, jakie Pinker włożył w przekonywanie, że żyjemy w najbardziej pokojowym okresie w historii ludzkości. Długi Pokój, który miał sparaliżować wojenne wysiłki państw europejskich i wpłynąć na gwałtowne obniżenie poziomu agresji na całym świecie, jest wielokrotnie nazywany zjawiskem „historycznie bezprecedensowym”, „nagłym statystycznym spadkiem” (downslope), okresem, kiedy poziom przemocy stał się „pełzający” (ground-bugging) (Pinker 2011a: x, 224-225, 230). Próbując wyjaśnić przyczny tej rewolucyjnej zmiany, Pinker obala argumenty o nuklearnych, demokratycznych, liberalnych i kantowskich przyczynach pokoju, w niejasny sposób sugerując, że to postęp społeczny jest odpowiedzialny za Długi Pokój (Pinker 2011a: 268-294). Ów postęp miał być z kolei zależny od dialektyki łagodnej i gwałtownej strony ludzkiej natury. W tym miejscu złożoność przedmiotu badań daje o sobie znać: streszczone powyżej krytyki i wykazanie błędnego sposobu wnioskowania ze statystyk (Cirillo i Taleb 2016, Falk i Hildebolt 2017) podają w wątpliwość podstawowe wnioski Pinkera. W rezultacie wszelkie próby używania tych wniosków do wyjaśnienia bardziej skomplikowanych procesów, w tym przyczyn „rewolucji Długiego Pokoju”, skazane są na niepowodzenie. Powstaje sytuacja, której Pinker łatwo mógłby uniknąć, gdyby spróbował w większym stopniu oprzeć się na istniejących dokonaniach teoretyków społecznych i socjologów historycznych.

Innym aspektem tego problemu sa postulaty zawarte w pracy. Celem Pinkera było doprowadzenie do swego rodzaju rewolucji naukowej-zmiany myślenia o czasach współczesnych jako okresie szczególnie brutalnym. 
Czytelnicy mieli docenić fenomenalna pokojowość naszych czasów i zaczać kierować się rodzajem racjonalnego optymiz̨mu. Celem Pinkera było więc nie tylko udowodnienie pewnej prawdy na temat przeszłości i współczesności, ale również coś o rysach erudystycznej perswazji. Wymagało to zastosowania w tekście licznych narzędzi retorycznych. Stąd też z pracy dowiemy się, że miała ona dotknać „być może najważniejszego problemu w historii ludzkości" (Pinker 2011a: i), a historyczne przykłady optymizmu mimo przemocy stosowanej przez ludzi przedstawiane zostały jako nieświadome proroctwa „słuszne w każdym wypadku” (Pinker 2011a: 29). Nawet jeśli część zabiegów retorycznych nie była nakierowana na promowanie konkretnego światopoglądu, Pinker często przedkładał literackość nad precyzję przedstawienia rzeczywistości, czego końcowy efekt był podobny: odciagał uwagę od szczegółu na rzecz przewodniej tezy książki. W ten sposób zredukował motywacje uczestników turniejów rycerskich do popisów męskości (macho prowess), religię do ideologii, a zjawisko przemocy do śmierci per capita (Pinker 2011a: xxiv, 63-64, 673-675). Pinkerowska fascynacja zabiegami retorycznymi znalazła wyraz również w jego wcześniejszej publikacji dotyczącej stylu pisania (Pinker 2014). To do retoryki Zmierz̨chu præemocy odwoływali się krytycy, nazywając ja „,w dużej mierze instruktywną” (Gray 2011), apelując: „oszczędź nam mitologii” (Hart 2012), i wysuwajac oskarżenie o proponowanie postawy raczej niż tezy (Lerner 2012). Nassim Taleb, autor wnikliwej analizy metod Pinkera, stwierdził wręcz, że ten „nie jest w stanie określić jasnej różnicy pomiędzy nauka a dziennikarstwem czy pomiędzy metodycznym empirycyzmem a dowodami anegdotycznymi" (Taleb 2012). Zmieržch przemocy, mimo że mówi o licznych rewolucjach i obwieszcza rewolucyjną tezę, powstał pod ich wrażeniem raczej niż z chęci ich precyzyjnego opisania.

\section{/// Rewolucja człowieczeństwa według Harariego}

Harari, izraelski historyk wojskowości, stawia w swojej książce Od zwierz̨at do bogów. Krótka historia ludžoości jasno sformułowane, ale niezwykle skomplikowane pytanie: „w jaki sposób trzy wielkie rewolucje w dziejach ludzkości - kognitywna ${ }^{1}$, neolityczna i naukowa - wpłynęły na człowieka i inne ziemskie organizmy?” (Harari 2014: 3-4; polskie tłum. 2017). W odpowiedzi buduje narrację, w której zawierają się odniesienia do kolejnych, kon-

\footnotetext{
${ }^{1}$ Przez rewolucję kognitywną Harari rozumie pojawienie się nowych form komunikacji i myślenia poznawczego 70 do 30 tysięcy lat temu w związku z wielkimi migracjami z Afryki Wschodniej na Bliski Wschód i dalej do Azji Wschodniej, Ameryki i Australii.
} 
kretniejszych tez: o przełomowej roli rozwoju wyobraźni w ludzkiej dominacji wśród innych gatunków (22-30), o pokrewieństwie religii i struktur polityczno-prawnych jako wytworów ludzkiej wyobraźni (30-44), o rewolucji neolitycznej jako głównej przyczynie pogorszenia się warunków życia zwierząt wykorzystywanych przez człowieka (89-107), o stałym trendzie tworzenia się imperiów (210-232) czy o współczesnej nieprecyzyjnej ocenie wpływu postępu technologicznego na szacowany poziom zadowolenia z życia (421-442). Chociaż układ pracy (cztery części dotyczące kolejnych przełomów, które Harari dostrzegł w historii ludzkości, podzielone na dwadzieścia rozdziałów) jest chronologiczny i zawiera ona aparat naukowy w postaci przypisów, różni się od typowych wywodów historycznych. Harari zrezygnował ze źródeł pierwotnych jako chociażby uzupełniającego materiału bazowego dla wniosków; zamiast tego opiera się w całości na cudzych opracowaniach, a w przeważającej mierze - na syntezach. Choć nie gra to decydującej roli w ocenie wartości pracy, warto dodać, że nawet zawarte w niej odniesienia do istniejącej literatury są nieliczne (zaledwie kilka przypisów na rozdział).

Ostatnia część $O d$ żwierz̨at do bogón rozważa konsekwencje, jakie przyniosą rodzajowi ludzkiemu nowe technologie, włączając w to inżynierię genetyczna, nowe, hipotetyczne typy biochemii tworzące życie nieorganiczne oraz możliwość uczynienia ludzi nieśmiertelnymi (lub aśmiertelnymi - ammortal - czyli podatnymi jedynie na przemoc) (Harari 2014: 445-464). Zgodnie z metaforą Harariego oznaczałoby to, że „ludzie staną się bogami”. Wątek ten podejmuje kolejna książka izrealskiego historyka, Homo deus: krótka historia jutra (2016; polskie tłum. 2018). W o wiele większym stopniu poświęcona filozoficzno-kognitywnym fascynacjom Harariego, dotyka ona zagadnień inteligencji, świadomości i ludzkiego doświadczenia w ogóle. Jej przewodni argument da się streścić następującym wywodem logicznym: z ewolucyjnego punktu widzenia ludzie działaja według algorytmu, a dzięki kolejnym rewolucjom, szczególnie rewolucji naukowej, nauczyli się manipulować danymi, które ich tworzą, chociaż w procesie tym utracili błogą nieświadomość tego, czym naprawdę są. „Nowoczesność to umowa” - pisał Harari - „ludzie zgadzają się na porzucenie sensu życia w zamian za władzę [...]. Co jest cenniejsze - inteligencja czy świadomość?” (Harari 2016: 199). Konieczność odpowiedzi na to pytanie znamionuje nadchodzący koniec człowieka w jego dotychczasowej postaci: zmieni się das Menschsein selbst bądź dojdzie do katastrofy egzystencjalnej. Struktura książki w pełni oddaje charakter przedstawianej tezy - została podzielona na trzy części zatytułowane Homo sapiens podbija świat, Homo sapiens nadaje 
swiatu znaczenie oraz Homo sapiens traci kontrole. Homo deus oparty jest na bogatszej literaturze niż Od zwierz̨at do bogów, choć wciąż składa się jedynie z opracowań tematycznych.

Obie prace Harariego zajmują stanowisko wobec największych rewolucji w dziejach człowieka i przedstawiaja propozycję nadejścia kolejnej. Jakich metod użyto, żeby udowodnić tę tezę? Od zwierz̨at do bogón rozczarowuje, ponieważ powołuje się na poziom rozwoju technologicznego jako jedyny argument, który ma dowieść nadejścia rewolucji społeczno-technologicznej mającej „zmienić oblicze człowieka” (Harari 2014: 445-446). Chociaż obawy przed konsekwencjami niekontrolowanego rozwoju nie sa bezpodstawne, zakładanie konkretnego scenariusza tylko w oparciu o reakcję emocjonalną (strach) zakrawa na sensacjonalizm. Bezcelowość tego rodzaju przewidywań dobrze udowadnia fakt, że od lat 50. XX wieku eksperci szacują czas potrzebny na wynalezienie sztucznej inteligencji na mniej więcej dwadzieścia lat (Bostrom 2014: 3-4). Humanizm, w nomenklaturze Harariego religia (sic!) przekonana o prymarnej roli moralnej jednostkowo pojmowanego szczęścia (raczej charakterystyka niż precyzyjna definicja), popchnie człowieka ku pogoni za władzą i nieśmiertelnością. Sięgnięcie po te boskie atrybuty może odbyć się kosztem człowieczeństwa i doprowadzić do rozpłynięcia się indywidualizmów w Internecie-Wszystkich-Rz̨eczy, systemie danych, który przewyższy sprawnością człowieka (Harari 2016: 94-107). Emocjonalno-intuicyjna probabilistyka Harariego przechodzi w karykaturę, jeśli wziąć pod uwagę szczegółowość jego propozycji. Wydaje się, że porzucił on naukowe metody dochodzenia do przyczyn rewolucji na rzecz wyjaśnienia opartego na dość swobodnie rozumianej ideologii i jej interakcji z technologią, miejsca zaś poświęcone społecznym oddźwiękom przepowiadanych zmian (np. Harari 2016: 46-52, 65-72) zawierają spekulację ekstrapolowana $z$ technicznych nowinek.

Futurystyczną metodę Harariego można by nazwać erudite guess, erudycyjnym zgadywaniem, opartym na naiwnym przekonaniu, że ewolucję da się przedstawić jako narrację linearnego postępu. Jednakże nawet to określenie nie wytrzymuje nacisku zarzutów, z jakim spotkały się obie omawiane prace. Szczegółowo opisano zawarte w nich pominięcia, uproszczenia i niesatysfakcjonujące generalizacje (Strawson 2014, Sexton 2015, Tuschman 2015). Wielokrotnie powracały też zarzuty wyciągania doniosłych wniosków bez żadnej podstawy źródłowej (Mann 2015, Sexton 2015). Wypominano też tendencję do scientific name-dropping - przesadnego użycia słów takich jak biotechnologia, nanotechnologia czy sztuczna inteligencja, podczas gdy rzadko którykolwiek z tych tematów jest głęboko omówiony 
(„Future Shock” 2016). W szczegółowej analizie amerykański antropolog C.R. Hallpike (2017) nie dostrzegł w książce ,żadnego wkładu do zastanego stanu wiedzy” i sugerował, żeby „,nie oceniać Od zwierzą do bogów jako poważnej pracy naukowej, ale raczej jako «infotainment», publikację nastawioną na zabawienie czytelników dziką intelektualną przejażdżką przez krajobraz historii, zakrapianą sensacjonalną spekulacją i zakończoną ekscytującymi prognozami końca ludzkości”. W tym sensie miał to być „absolutny sukces". Nawet Pinker dystansował się od porównania z Hararim, twierdząc, że jest „sceptyczny wobec wyobrażonych scenariuszy science fiction" (Sailer 2015). Do wspomnianych warto dodać również zrekapitulowane powyżej braki metodologiczne oraz emocjonalne zaangażowanie w omawiany temat. Harari, podobnie do Pinkera, posłużył się w swoich pracach silną retoryką. Przejawiła się ona w konstrukcji całej książki: porzucono w niej typową dla literatury anglojęzycznej strukturę argumentacyjną, gdzie każdy element wywodu podporządkowany jest udowodnieniu przewodniej tezy (Aumüller 2014: 854-867). Zamiast tego treść pracy, pozornie dyktowana jej chronologicznym układem, bezustannie od niego odbiega, przekonując do kolejnych uderzających faktów na temat tego, jak daleko zaszliśmy jako gatunek i przygotowując czytelnika do bezkrytycznego przyjęcia równie uderzających zwiastunów przyszłości. Exempli gratia, pierwszy rozdział Homo deus przekonuje, że poprzez coraz wyższą skuteczność w walce z chorobami, głodem i skrajnym ubóstwem człowiek uniezależnia się od biologii. Natychmiast później Harari zaczyna odgadywanie przyszłości, przejście pomiędzy tymi fragmentami sprowadzając do frazy o zakładanym przez niego prawdopodobieństwie, np. „,w XXI wieku ludzie najpewniej podejmą poważną próbę osiągnięcia nieśmiertelności”, „drugim wielkim punktem w planie ludzkości na przyszłość prawdopodobnie będzie odnalezienie klucza do szczęścia" (Harari 2016: 4, 5-6). W ten sposób nie tylko przyzwyczaja czytelnika do zrównywania faktów i spekulacji, ale też legitymizuje swoje twierdzenia za pomocą argumentu emocjonalnego: skoro tyle już udało się nam osiągnać, co jeszcze przed nami?

\section{/// Dlaczego tyle rewolucji, dlaczego tak mało o rewolucjach?}

Zagadnienie rewolucji jest symptomatyczne dla postawy popnaukowców. Mimo że przedmiotem ich prac była rewolucyjna zmiana społeczna, a używany przez nich język oraz retoryka nawiązywały do licznych rewolucji, zarówno Pinker, jak i Harari zupełnie zignorowali dotychczasową literaturę dotyczącą tematu. Tymczasem teoria rewolucji ma długą tradycję (Kro- 
eber 1996). Dla Marksa rewolucja była warunkiem postępu społecznego i krytycznym efektem walki klas. Przez kolejne sto pięćdziesiąt lat szkoły marksistowskie i neomarksistowskie, niezależnie od swojego stosunku do rewolucyjnego postulatu, musiały odnieść się do rewolucji jako do newralgicznego punktu teorii, na której się opierały (Schaff 1973). Pitrim Sorokin, odwołując się do Hobbesa, szukał przyczyn rewolucji w dezorganizacji instytucji władzy i społecznej kontroli oraz w stłumieniu podstawowych instynktów, jakie odczuwa większość społeczeństwa (Sorokin 1925). Podejścia strukturalistyczne pozwoliły wyróżnić, poza bezpośrednimi przyczynami rewolucji, rewolucyjną sytuację społeczną związaną z długofalowymi procesami. Theda Skocpol udowodniła, że w rewolucji zawiera się etap kryzysu stanu oraz wyłonienia się klasy, która później dominuje porewolucyjną rzeczywistość (Skocpol 1979). Charles Tilly wskazał na znaczenie przesunięć definicyjnych granic rewolucji, przy których niewielka zmiana może doprowadzić do ogromnych różnic teoretycznych (Tilly 1978). W reakcji na niezwykle istotną książkę Thomasa Kuhna (1962) pojawiły się dziesiątki prac mówiących o rewolucji w nauce. Wreszcie, sama rewolucja technologiczna ostatnich lat opisywana jest w o wiele dojrzalszej i mniej spekulatywnej formie przez badaczy o różnych specjalizacjach (Anton, Silberglitt i Scheider 2001, Klein 2008, Perez 2009). Pominięcie tradycji pisania o rewolucjach to zarzut, który w oczach każdego recenzenta niebezpiecznie podważałby zasadność wniosków pracy w dużym stopniu poświęconej rewolucjom. Dlaczego więc doświadczeni badacze - Pinker to znakomity autorytet $\mathrm{w}$ zakresie psychologii ewolucyjnej i kognitywistyki, Harari jest szanowanym specjalista od historii militarnej - dopuścili się takiego zaniedbania?

Najprostsze wyjaśnienie wskazywałoby na to, że adresatem ich ksiażek nie byli tylko naukowcy - dlatego zdecydowano się na podkreślenie centralnej tezy zamiast wchodzenia w szczegółowe debaty akademickie. Popnaukowcy obroniliby się przed wieloma krytykami, przyjmując etykietę popularyzatorów bądź dziennikarzy, faktycznie jednak wystrzegają się tego porównania (Ni 2008). Zamiast tego uparcie przekonuja o naukowej doniosłości swoich wniosków, nie widząc sprzeczności między tym a deklarowaniem, że ich „docelowym odbiorca jest czytelnik New York Timesa” (Ni 2008, Sanderson 2014). Ta konfuzja po części wynika ze specyfiki anglojęzycznych rynków wydawniczych, które często zacierają różnicę pomiędzy jednym a drugim. W prasie (oraz e-prasie) obu określeń używa się wymiennie - np. na stronie wydawnictwa Penguin Od zwierzat do bogów umieszczona jest w kategorii „Popular science”, chociaż samej pozycji 
towarzyszy dopisek „Special editions of groundbreaking science books” (patrz: https://www.penguin.co.uk/genres/non-fiction/science-nature/ popular-science/; dostęp 10.01.2018; podobnie Ellis 2015). W rezultacie wnioski popnaukowców są raz odrzucane jako popularyzatorskie, przez co nie stosuje się wobec nich takich samych standardów jak wobec poważniejszych prac (Ni 2008, Fuentes 2017), a raz szczegółowo krytykowane przez specjalistów, którzy alarmują o „infotainment” oraz niedostrzeganiu „różnicy pomiędzy nauką i dziennikarstwem”. Niebezpieczeństwo pojawia się, kiedy trafią do rąk osób nieświadomych tej różnicy lub krytyk, a szczególnie badaczy niepowiązanych dyscyplin, którzy nie są w stanie dostrzec nadużyć. Tych, którzy sądzą, że nie dzieje się to tak często, warto ponownie odesłać do baz zbierających informacje na temat cytowań umieszczanych w artykułach akademickich, takich jak Google Scholar.

Być może głównym problemem jest właśnie to, że prace popnaukowe nie spełniają ani warunków stawianych tekstom naukowym, ani popularnym, popularyzatorskim czy popularnonaukowym. Mają one wprawdzie aparat naukowy (bardziej rozwinięty u Pinkera) i opierają się na licznych, często znamienitych nazwiskach oraz teoriach; próbują też w uporządkowany i racjonalny sposób odpowiedzieć na ważne dla nauki pytania: nie są więc „wiedzoodtwórcze”, ale „wiedzotwórcze”, co jest cechą działalności naukowej (Załęska 2016: 60-61). Posługują się jednak uogólnieniami, są niedokładne, zarzuca się im uprzedzenia. Zaniedbane są w nich fragmenty poświęcone metodom i założeniom teoretycznym; nacisk argumentacji zamiast na dane i sposoby ich opracowania kładzie się na emocje; wiedza nie jest w nich celem, ale środkiem do osiagnięcia celów pozanaukowych; ich język jest dostrojony do szerokiej publiczności. Ta charakterystyka wskazywałaby z kolei na to, że są to prace popularyzatorskie (Załęska 2016: 64-68). Wydawca omawianych książek, Penguin, specjalizuje się w publikacjach beletrystycznych i popularnonaukowych. Nawet tytuły prac Harariego, A Brief History of..., wyraźnie nawiazuja do formatu popularyzatorskiego. Tymczasem popnaukowcy uparcie twierdzą, że ich publikacje sa przełomowe w znaczeniu przede wszystkim naukowym; pogląd, który wielu cytujących wydaje się podzielać.

O ile twierdzenie, że popnauka to po prostu próba formułowania wniosków pretendujących do naukowości za pomoca metod, które nie spełniają kryteriów naukowych, w części tłumaczy ich popularność pośród laików, o tyle nie wyjaśnia ono, dlaczego książki Pinkera i Harariego odniosły sukces w środowisku akademickim. Naiwne byłoby założenie, że każdy badacz, który odebrał je entuzjastycznie, nie zdaje sobie sprawy z ich

\section{/ 190 STANRZECZY 1[14]/2018}


wad i przesycenia retoryką. Ważnym czynnikiem mogą być natomiast prady myślowe, które każą odkrywczość tezy docenić w większym stopniu niż metodologiczny rygor analizy. Najogólniej wskazać można na to, że świat anglosaski, mimo że zwykle wiązany z filozofią analityczną nakierowaną na dokładność i detal, pozostaje również pod wpływem myśli utylitarnej i pragmatycznej, zorientowanych na postęp społeczny oraz stosowalność proponowanych rozwiązań (Morales 2017). Trend ten znajduje swój szczególny wyraz w historiografii, gdzie sukces odnosza prace podporządkowujące historiografię celom wobec niej zewnętrznym bądź „twardym” dziedzinom, które w domyśle maja zrobić z niej lepszy użytek. Renesans przeżywa historia globalna, często wiązana ze społecznym zaangażowaniem historyka (Armitage i Guldi 2015), która wydała już na świat prognostyków katastrofy, jaka przyniesie rozwój - nie bez przypadku Fukuyama (1992) również wygłaszał tezy o posthumanizmie i nieagresji dojrzałych demokracji. Tymczasem od publikacji nagrodzonych nagrodą Pulitzera Strzelb, zarazków, maszyn (z alternatywnym podtytułem Krótka historia wszystkiego. Ostatnie 13 tys. lat) Jareda Diamonda (1997) trwaja debaty na temat stosowania narzędzi nauk przyrodniczych w badaniach historycznych. Podczas gdy zwolennicy takiego rozwiązania wskazują na korzyści, jakie przynieść może poszerzenie perspektywy i zwiększenie ilości dostępnych metod badawczych, ostrożniejsi metodologowie ostrzegaja przed możliwościa zamknięcia się w kręgu myślowym redukcjonistycznego ewolucjonizmu kulturowego oraz zagrożeniem kolonizacji jednych dyscyplin przez drugie, jeżeli taka adaptacja nastąpi z pominięciem złożoności problematyki historycznej (Blaser 1999, Goodheart 2005, Adas 2012, Chase-Dunn i Hall 2012, Wieseltier 2013, Izdebski 2014).

Sa powody, żeby sądzić, że popnaukowcy nie traktują nauk społecznych i humanistycznych jako równorzędnych innym dziedzinom. Pinker był jednym z beneficjentów tzw. zwrotu kognitywnego w nauce, który zaowocował nagłym zwiększeniem nakładów finansowych na studia nad mózgiem i umysłem w ostatnim ćwierćwieczu poprzedniego stulecia (Abbott 2008). Interdyscyplinarny charakter tych badań, skupiających przedstawicieli „twardych” i „miękkich” nauk (psychologów, neurobiologów, lingwistów i specjalistów od sztucznej inteligencji, ale też antropologów i filozofów) mógł poskutkować tym, że absolwenci widziani byli (oraz widzieli siebie) jako kompetentnych w każdej z tych sfer. Nieprzypadkowo po pracy $\mathrm{w}$ instytucjach poświęconych neuronauce Pinker otrzymał posadę w londyńskim New College of the Humanities. Podobne zaplecze w „twardej" nauce ma wielu innych popnaukowców: Ray Kurzweil to informa- 
tyk i futurysta, Robert Wright specjalizuje się w psychologii ewolucyjnej, Michael Shermer - w psychologii eksperymentalnej. Harari to wprawdzie historyk, ale historyk wojskowości, niezainteresowany głębokimi przemianami społecznymi przed publikacją swoich bestsellerów. Możliwe, że wielu z omawianych badaczy wychodzi z przekonania, wcale zresztą nie marginalnego, że humanistykę i nauki społeczne uprawia się łatwo (Lewis 2017).

Te uprzedzenia idą w parze z sympatią, jaką żywią oni do propozycji mechanistycznego opisu kultury; przy okazji powracaja podnoszone podczas dyskusji wokół książki Diamonda oskarżenia o scjentyzm, naukowa kolonizację i wiarę w prymat biologii nad kulturą. Pinker widzi siebie jako proponenta integracji nauk ścisłych i humanistycznych, przekonując, że to jedyny ratunek wobec ich kryzysu (Pinker 2013), oraz sugeruje mariaże, które istnieją już od dawna: lingwistyki z literaturoznawstwem, semantyki i historii, psychologii i biologii z naukami politycznymi (,Towards a Greater Synthesis" 2016). Odrzucenie uproszczeń zawartych w pracach popnaukowców zrównuje z oporem wobec adaptacji metod nauk przyrodniczych w naukach społecznych i komentuje z wyraźną irytacją:

Humaniści [...] siegają po zwyczajowe przymiotniki: upraszczające, redukcjonistyczne, naiwne, wulgarne, i oczywiście, scjentystyczne [...] krytycy powinni uważać z przymiotnikami. Jeżeli cokolwiek jest naiwne i upraszczające, to jest to przekonanie, że wrota akademii powinny być zatrzaśnięte i że powinniśmy być wiecznie usatysfakcjonowani tym, jak naukę robi się dziś. Z pewnością nasze zrozumienie polityki, kultury i moralności może wiele zyskać dzięki zrozumieniu świata fizycznego czy historii człowieka jako gatunku (Pinker 2013).

W podobnym duchu Harari w pierwszych słowach Sapiens sytuuje historię jako naukę o kulturze w szkielecie nauk przyrodniczych (Harari 2014: ix) oraz - co istotniejsze - umieszcza w książce podziękowania dla Jareda Diamonda, który udowodnił mu, że „można zadawać wielkie pytania i odpowiadać na nie naukowo" (481-482). Niektórzy publicyści dopatrują się w tym powstawania odrębnej szkoły badawczej, która ma „stosować metody nauk ścisłych do badania każdego aspektu historii” (Forbes 2014). Popnauka łączy przekonanie o skuteczności takiego projektu z perspektywą makrohistoryczną i zbywającym stosunkiem wobec teorii w ogóle. Prace Harariego dają wyraz przekonaniu, że da się pisać historię uniwersalna, przechodząca ponad przestrzennymi i czasowymi granicami, mimo bra- 
ku szczegółowego zagłębienia się w którykolwiek z omawianych tematów. Pinker wydaje się wychodzić z założenia, że do wsparcia głęboko skontekstualizowanych twierdzeń dotyczących społeczno-historycznego rozwoju wystarcza podobna ilość odniesień do literatury, co w przypadku uzasadnienia eksperymentalnie sprawdzalnych twierdzeń nauk kognitywnych, wyabstrahowanych na potrzeby operacyjne. Dostrzeżone w tej sposób zależności ilustrowane są z kolei wycinkami z filozoficznych prac z epoki, podobnie jak psychologowie ilustruja procesy psychologicznie przykładami z życia codziennego. Metodologiczne braki w obu przypadkach przykryte są literacką retoryką i przywoływaniem ustaleń nauk „ścisłych”. Biologia, informatyka i statystyka mają według popnaukowców uszlachetniać każda kiepską socjologię.

Podczas próby diagnozy problemu popnaukowców wskazać należałoby również na inny rodzaj afiliacji. Poza podobnym wykształceniem, postawą i cechami pisarstwa omawiani badacze związani są z tzw. Nowym Ateizmem oraz uważani są za autorytety przez członków grup transhumanistycznych. Nowy Ateizm to ruch pisarzy ateistycznych, którzy postawili sobie za zadanie rozciagnięcie naukowego rozumowania na teren religii w ramach debaty publicznej (LeDrew 2016: 46-54). Chociaż jego najsłynniejsi członkowie to także publiczni intelektualiści wywodzący się ze środowiska naukowego (Richard Dawkins, Sam Harris, Christopher Hitchens i Daniel Dennett, w nawiązaniu do końca religii nazywani „Czterema Jeźdźcami”), ich celem jest rozpowszechnianie wiedzy (działalność „wiedzoodtwórcza”) na polach wyznaczonych przez ich specjalizacje. To nie pozwala zaliczyć ich do grupy popnaukowców, ponieważ ściśle przestrzegaja rozróżnienia pomiędzy działalnością naukową i popularyzatorska. Wiele wskazuje jednak na to, że jedni i drudzy mają tych samych odbiorców. Pinker jest bezpośrednio kojarzony z Nowym Ateizmem (LeDrew 2016: 51). Harari, w kilku miejscach krytyczny wobec tego ruchu, jest aktywnym zwolennikiem ateizmu, w obu książkach powołuje się na „Czterech Jeźdźców” (Harari 2014: 443, Harari 2016: 116, 196, 305) oraz przyją zaproszenie Harrisa na wywiad w jego podcaście (Harris 2017). Tytuły wzmiankowanych książek powinny wyjaśnić przyczyny fascynacji popnauką wśród grup skupionych wokół pojęcia transhumanizmu, czyli zwolenników wykorzystywania technologii do rozwoju ludzkiej kondycji i zainteresowanych jej futurystycznym obrazem. Transhumaniści tworza zbiorowości pozostające w kontakcie dzięki mediom społecznościowym, uaktywniające się blisko specyficznych dat (np. 1 marca, czyli Dzień Przyszłości czy 1 października, czyli Dzień Długowieczności) i zorganizowane 
wokół konkretnych organizacji (np. Humanity+ i Church of Eternal Life). Harari (2016: 352-266) bezpośrednio przyznaje się do tego rodzaju fascynacji; Pinker mial „przecierać szlaki” transhumanizmowi (Baumann 2010).

W obliczu tych związków i wspomnianych wcześniej oskarżeń o promowanie danej postawy, nie trzeba dedukcyjnej brawury popnaukowców, żeby wskazać na zagrożenie ideologizacją. Pomimo ich najlepszych intencji kierowany racjonalnym lub oświeconym optymizmem redukcjonistyczny scjentyzm Harariego, Pinkera i innych oddala popnaukę od nauki, której ostatecznym celem - według wielu - ma być prawda. Problem dobrze obrazuje przykład Michaela Shermera, transhumanisty, makrohistoryka nauki, wojującego ateisty i popnaukowca polecanego przez Pinkera. W 2017 opublikował on w czasopiśmie „Theology and Science” programowy tekst pod tytułem Scientific Naturalism: A Manifesto for Enlightenment Humanism. Z wykształcenia będący m.in. teologiem Shermer w sposób symptomatyczny zmieszał w nim twierdzenia społeczno-historyczne z postulatami odnośnie do postawy. Przekonywał, że to dzięki tytułowemu światopoglądowi ,już nigdy więcej nie będziemy intelektualnymi niewolnikami tych, którzy mózgi nasze skuliby łańcuchami dogmatu i autorytetu" (Shermer 2017: 228).

Nawet zgadzając się z pobudkami Shermera, nie sposób zgodzić się z jego metodami, zarówno dotyczącymi przeprowadzania badań, jak i komunikacji ich wyników. Jeśli ważne pozostają takie cechy nauki, jak obiektywizm i racjonalizm, to argument nawołujący do akceptacji postawy naukowej oparty na emocjach będzie sam siebie podważał. Podobnie, być może, należy docenić ambitne projekty Harariego i Pinkera, ale nie można przyjmować ich bezkrytycznie. Bogate statystyki i błyskotliwe uwagi zawarte w ich książkach przyćmione zostały ostentacyjnością ich wniosków. Przewidywania przyszłości oparte na tak chybotliwych fundamentach nie dowartościowują ani nie wnoszą wiele do naszych niełatwych prób podejmowania się społecznej futurologii. O ile nie sposób sprowadzić książek popnaukowców do zwykłego science fiction, o tyle z pewnością mogą klasyfikować się jako non-fiction i niebezpiecznie zbliżają się do non-science.

Bibliografia:

/// Abbott L.F. 2008. Theoretical Neuroscience Rising, „Neuron”, t. 60, nr 3, s. 489-495. 
/// Adas M. 2012. Comparative History and the Challenge of the Grand Narrative, [w:] A Companion to World History, red. D. Northrop, Blackwell Publishing, s. 229-243.

/// Anton P.S., Silberglitt R., Schneider J. 2001. The global technology revolution: bio/nano/materials trends and their synergies with information technology by 2015, Rand Corporation.

/// Armitage D., Guldi J. 2015. The History Manifesto, Cambridge University Press.

/// Aronson R. 2013. Pinker and Progress, „History and Theory”, t. 52, nr 2, s. 246-264.

/// Arquilla J. 2012. The Big Kill, „Foreign Policy”. https://foreignpolicy. com/2012/12/03/the-big-kill/; dostęp: 05.01.2018.

/// Aumüller M. 2014. Text Types. Handbook of Narratology, De Gruyter.

/// Baumann F. 2010. Humanism and Transhumanism, „The New Atlantis”, t. 29 , s. $68-84$.

/// Bhatt C. 2013. Book Review Symposium: Steven Pinker, The Better Angels of Our Nature: A History of Violence and Humanity, „Sociology”, t. 47, nr 6, s. $1229-1232$.

/// Black J. 1995. A Military Revolution? A 1660-1792 Perspective, [w:] J. Rogers, The Military Revolution Debate: Readings on the Military Transformation of Early Modern Europe, Westview Press, s. 95-115.

/// Blaser K. 1999. The History of Nature and the Nature of History: Stephen Jay Gould on Science, Pbilosopby, and History, „The History Teacher”, t. 32, nr 3, s. 411-430.

/// Boström N. 2014. Superintelligence: Paths, dangers, strategies, Oxford University Press.

/// Chase-Dunn C., Hall T.D. Global Scale Analysis in Human History, [w:] A Companion to World History, red. D. Northrop, Blackwell Publishing, s. $185-200$.

/// Cirillo P., Taleb N. 2016. On the statistical properties and tail risk of violent conflicts, „Physica A: Statistical Mechanics and its Applications”, t. 452, s. $29-45$. 
/// Diamond J. 1997. Guns, Germs, and Steel: The Fates of Human Societies, W.W. Norton.

/// Douthat R. 2011. Steven Pinker's History of Violence, „The New York Times". https://douthat.blogs.nytimes.com/2011/10/17/steven-pinkers-history-of-violence; dostęp: 04.01.2018.

/// Duffy M. 1980. The Military Revolution and the State, 1500-1800, University of Exeter Press.

/// Ellis R. 2015. 'Sapiens' by Yuval Noab Harari, „Middle Way Society”. http://www.middlewaysociety.org/books/science-and-social-science-books/sapiens-by-yuval-noah-hariri/; dostęp: 08.01.2018.

/// Epstein R. 2011. Book Review: The Better Angels of Our Nature: Why Violence Has Declined, „Scientific American”. https://www.scientificamerican.com/ article/bookreview-steven-pinker-the-better-angels-of-our-nature-whyviolence-has-declined/\#; dostęp: 04.01.2018.

/// Falk D., Hildebolt C. 2017. Annual War Deaths in Small-Scale versus State Societies Scale with Population Size Rather Than Violence, „Current Anthropology", t. 58, nr 6, s. 805-813.

/// Ferguson R.B. 2013. Pinker's List. Exaggerating Prehistoric War Mortality, [w:] War, Peace, and Human Nature. The Convergence of Evolutionary and Cultural Viens, red. D. Fry, Oxford University Press, s. 112-131.

/// Forbes P. 2014. Sapiens by Yuval Noah Harari, book review: Eloquent history of what makes us buman. http://www.independent.co.uk/arts-entertainment/books/reviews/sapiens-by-yuval-noah-harari-book-review-eloquenthistory-of-what-makes-us-human-9712106.html; dostęp: 11.01.2018.

/// Fuentes A. 2017. Get the Science Right!, „Psychology Today”. https://www. psychologytoday.com/blog/busting-myths-about-human-nature/201707/ get-the-science-right; dostęp: 10.01.2018.

/// Fukuyama F. 1992. The End of History and the Last Man, Free Press.

/// Future shock. The bestselling Israeli historian looks at where mankind is heading. 2016. „The Economist”. https://www.economist.com/news/books-andarts/21707180-bestselling-israeli-historian-looks-where-mankind-headingfuture-shock; dostęp: 08.01.2018. 
/// Gray J. 2011. Delusions of Peace, „Prospect”. https://www.prospectmagazine.co.uk/magazine/john-gray-steven-pinker-violence-review; dostęp: 05.01.2018.

/// Goodheart E. 2005. Is History a Science?, „Philosophy and Literature”, t. 29, nr 2, s. 477-488.

/// Hallpike C.R. 2017. A Response to Yuval Harari's 'Sapiens: A Brief History of Humankind”, „New English Review”. http://www.newenglishreview.org/ custpage.cfm?frm=189085\&sec_id=189085; dostęp: 09.01.2018.

/// Harari Y.N. 2014. Sapiens: A Brief History of Humankind [oryg. wyd. hebrajskie 2011], Penguin.

/// Harari Y.N. 2016. Homo Deus: A Brief History of Tomorrow [oryg. wyd. hebrajskie 2015], Penguin.

/// Harari Y.N. 2017. Sapiens. Od zwierzat do bogów, tłum. J. Hunia, Wydawnictwo Naukowe PWN.

/// Harari Y.N. 2018. Homo deus. Krótka historia jutra, tłum. M. Romanek, Wydawnictwo Literackie.

/// Harris S. 2017. Reality and the Imagination. A Conversation with Yuval Noah Harari. https://www.samharris.org/podcast/item/reality-and-the-imagination; dostęp: 12.01.2018.

/// Hart D.B. 2012. The Precious Steven Pinker, „First Things”. https:// www.firstthings.com/article/2012/01/the-precious-steven-pinker; dostęp: 04.01.2018.

/// Herman E.S., Peterson D. 2012. Steven Pinker on the Alleged Decline of Violence, „International Socialist Review”, nr 86. https://isreview.org/issue/86/steven-pinker-alleged-decline-violence; dostęp 05.01.2018.

/// Izdebski A. 2014. Konwergencja nauk przyrodniczych i historycznych: teoretyczny potencjat i praktyczne trudności, „Historyka. Studia metodologiczne”, t. 44, s. 67-94.

/// Jervis R. 2011. Review: Pinker the Prophet, „The National Interest”, nr 116, s. 54-64.

/// Kolbert E. 2011. Peace in Our Time, „The New Yorker”. https://www.newyorker.com/magazine/2011/10/03/peace-in-our-time-elizabeth-kolbert; dostęp: 06.01.2018. 
/// Kranzberg M. 1986. Technology and History: „Kran₹berg's Laws”, „Technology and Culture", t. 27, nr 3, s. 544-560.

/// Kroeber C.B. 1996. Theory and History of Revolution, ,Journal of World History", t. 7, nr 1, s. 21-40.

/// Kuhn T. 1962. The Structure of Scientific Revolutions, University of Chicago Press.

/// Laws B. 2011. Theory Beyond the Codes, „CTheory”. http://www.ctheory. net/articles.aspx?id=702; dostęp: 04.01.2018.

/// LeDrew S. 2016. The Evolution of Atheism: The Politics of a Modern Movement, Oxford University Press.

/// Lerner C.S. 2012. Have a Nice Millenium, „The Claremont Review of Books". http://www.claremont.org/crb/article/have-a-nice-millennium/; dostęp: 05.01.2018.

/// Lewis C.S. 2017. Crisis Rhetoric, Stigma Play: The Contested Status of Humanities Majors on an Elite University Campus, „Symbolic Interaction”, t. 40, nr 3, s. 378-395.

/// Mann C.C. 2015. How Humankind Conquered the World, „,The Wall Street Journal". https://www.wsj.com/articles/book-review-sapiens-a-brief-historyof-humankind-by-yuval-noah-harari-1423261230; dostęp: 09.01.2018.

/// Mitzen J. 2013. The Irony of Pinkerism, „American Political Science Association", t. 11 , nr 2, s. 525-528.

/// Morales A. 2017. Renascent pragmatism: Studies in law and social science, Taylor \& Francis.

/// Ni N. 2008. The Pop-Science Paradox, „The Harvard Crimson”. http:// www.thecrimson.com/article/2008/5/2/the-pop-science-paradox-on-the-first/; dostęp: 09.01.2018.

/// Perez C. 2009. Technological revolutions and techno-economic paradigms, Working Papers in Technology Governance and Economic Dynamics, Working Paper No. 20, Norway and Tallinn University of Technology.

/// Pinker S. 2011a. The Better Angels of Our Nature: Why Violence Has Declined, Penguin Books.

/// Pinker S. 2011b. Frequently Asked Questions about The Better Angels of Our Nature: Why Violence Has Declined. https://stevenpinker.com/pages/frequ- 
ently-asked-questions-about-better-angels-our-nature-why-violence-hasdeclined; dostęp: 08.01.2018.

/// Pinker S. 2013. Science is Not Your Enemy, „New Republic”. https:// newrepublic.com/article/114127/science-not-enemy-humanities; dostęp: 07.01.2018.

/// Pinker S. 2014. The Sense of Style: The Thinking Person's Guide to Writing in the 21st Century, Penguin Books.

/// Pinker S. 2015. Zmierzch przemocy. Lepsza strona naszej natury, thum. T. Bieroń, Wydawnictwo Zysk i S-ka.

/// Sailer S. 2015. Pinker v. Singularity Think. The Unz Review. http://www. unz.com/isteve/pinker-v-singularity-think/; dostęp: 08.01.2018.

/// Sanderson C. 2014. Yuval Noah Harari: Interview, „The Bookseller”. https://www.thebookseller.com/profile/yuval-noah-harari-interview; dostęp: 09.01.2018.

/// Sexton J. 2015. A Reductionist History of Mankind, „The New Atlantis”, t. 47, s. 109-120.

/// Schaff A. 1973. Marxist Theory on Revolution and Violence, „Journal of the History of Ideas", t. 34, nr 2, s. 263-270.

/// Shermer M. 2017. Scientific Naturalism: A Manifesto for Enlightenment Humanism, „Theology and Science”, t. 15, nr 3, s. 220-230.

/// Skocpol T. 1979. States and Social Revolutions, Cambridge University Press.

/// Sorokin P. 1925. Sociology of Revolution, J.B. Lippincott.

/// Strawson G. 2014. Sapiens: A Brief History of Humankind by YuvalNoah Harari - review, „The Guardian”. https://www.theguardian.com/books/2014/ sep/11/sapiens-brief-history-humankind-yuval-noah-harari-review; dostęp: 08.01.2018.

/// Taleb N. 2012. The 'Long Peace' Is a Statistical Illusion. https://www.fooledbyrandomness.com/pinker.pdf; dostęp: 04.01.2018.

/// Tegmark M. 2017. Life 3.0: Being Human in the Age of Artificial Intelligence, Knopf.

/// Tilly C. 1978. From Mobilization to Revolution, McGraw-Hill. 
/// Towards a Greater Synthesis: Steven Pinker on How to Apply Science to the Humanities. 2016. „Farnam Street”. https://www.farnamstreetblog.com/2016/03/ steven-pinker-science-humanities/; dostęp: 10.01.2018.

/// True J. 2015. Winning the Battle but Losing the War on Violence. A Feminist Perspective on the Declining Global Violence Thesis, „International Feminist Journal of Politics", t. 17, nr 4, s. 554-572.

/// Tuschman A. 2015. How bumans became buman, „The Washington Post". https://www.washingtonpost.com/opinions/our-kind-of-people /2015/03/13/78404422-b84c-11e4-aa05-1ce812b3fdd2_story.html?utm_ term=.830680f30ef6; dostęp: 08.01.2018.

/// Wieseltier L. 2013. Crimes Against Humanities, „New Republic”. https:// newrepublic.com/article/114548/leon-wieseltier-responds-steven-pinkersscientism; dostęp: 10.01.2018.

/// Załęska M. 2016. Retoryczne aspekty popularyzacji naukowej, „Acta Universitatis Lodziensis. Folia Litteraria Polonica", t. 31, nr 1, 59-70.

\section{/// Abstrakt}

Artykuł omawia zjawisko popnauki oraz podejmuje próbę nakreślenia przyczyn jej powstania i sukcesu, jaki osiągnęła zarówno w kulturze popularnej, jak i w środowisku akademickim. Centralne pojęcie, angielski skrót od „popularyzacji nauki”, rozumiane jest tutaj jako prąd piśmiennictwa akademickiego przedstawiający śmiałe tezy z niezachwianym przekonaniem o ich wartości naukowej pomimo rażących braków metodologicznych. Zagadnienie rewolucji, przez pryzmat którego przejawia się stosunek popnaukowców do tradycji socjologicznej, stanowi oś wywodu. Autor analizuje model argumentacji przykładowych prac Stevena Pinkera i Yuvala Noaha Harariego oraz - na podstawie własnych wniosków i powracających krytyk - gromadzi jego składowe i odtwarza nieścisłości zastosowanego $\mathrm{w}$ nich rozumowania. W powiązaniu z kontekstem powstania omawianych książek elementy te pozwalają mu wskazać na źródła oraz potencjalne niebezpieczeństwa szerokiej legitymizacji popnauki.

Słowa kluczowe:

Pinker, Harari, metodologia, nauka, rewolucja 


\section{/// Abstract}

This article aims at describing the emergence of pop-science and its success both in popular culture and the academy. The key term, an English abbreviation of "popular science", is understood here as a tendency of some academic authors to posit a daring claim with full conviction of its validity despite its obvious methodological faults. The recurring theme of revolutions serves as a prism through which the pop-scientific attitude towards sociological tradition is presented. The critical analysis of works of Steven Pinker and Yuval Noah Harari and the collation of common critical arguments lead to extracting a set of constituents for the pop-scientific reasoning. The contextualisation of these elements allows exposing the sources and possible dangers of legitimising pop-science.

Keywords:

Pinker, Harari, methodology, science, revolution

/// Adrian D. Wesołowski - doktorant na Wydziale Historycznym Uniwersytetu Warszawskiego i w Instytucie Antropologii Społecznej Maxa Plancka w Halle an der Saale. Zajmuje się socjologia i antropologią historyczna, metodologia nauk społecznych oraz studiami nad sławą i społecznym wyróżnieniem. Niedawno publikował w „Kwartalniku Historycznym” oraz „Historyce. Studiach metodologicznych”. Laureat stypendium fundacji z Brzezia Lanckorońskich (2017).

Email: wesolowski@eth.mpg.de 